\title{
Development of epididymis and vas deferens in Galea spixii: an ultrastructural view
}

\author{
SANTOS, P. R. S. ${ }^{1 *}$, ARROYO, M. A. M. ${ }^{1}$, OLIVEIRA, M. F. ${ }^{2}$, MIGLINO, M. \\ A. ${ }^{1}$ and ASSIS NETO, A. C. ${ }^{1}$ \\ ${ }^{1}$ Department of Surgery, Faculty of Veterinary Medicine and Animal Science - FMVZ, \\ Universidade de São Paulo - USP, Avenida Prof. Dr. Orlando Marques de Paiva, 87, Cidade Universitária, \\ CEP 05508-270, São Paulo, SP, Brazil. \\ ${ }^{2}$ Department of Animal Science, Universidade Federal Rural do Semi-Árido - UFERSA, \\ Avenida Francisco Mota, 572, Costa e Silva, CEP 59625-900, Mossoró, RN, Brazil \\ *E-mail: pauloramos@usp.br
}

\begin{abstract}
The study aimed to characterize the ultrastructure of components of the sperm pathway in Galea spixii (Spix's yellow-toothed cavy) at different stages of sexual development. Segments of the epididymis and vas deferens of 10 Galea spixii were studied using scanning and transmission electron microscopy. Principal and basal cells with similar characteristics were seen in the epididymis and vas deferens. Both cell types are responsible for maturation of sperm as well as the ability to fertilize and reabsorption. The post natal morphological development of the epididymis and vas deferens was similar to testicular development of the species.
\end{abstract}

Keywords: genital organs, rodents, sexual development, Spix's yellow-toothed cavy, wild animals.

\section{Introduction}

Morphology of the male genital organs is important in determining sexual behavior, selection of breeding animals, and fertility (SHORT, 1979; EBERHARD, 1985). Gametogenesis occurs within the testis and is a synchronous process that regulates cellular differentiation within the seminiferous tubules and involves different classes of germ cells (COSTA, HENRY and PAULA, 2004) up to and including the formation of sperm. Once formed, sperm are directed to the epididymis. However, these sperm are neither motile nor fertile. During the passage through the epididymis, immature sperm undergo continuous and progressive changes in their composition to become fertile. The vas deferens reabsorbs sperm not expelled (HAFEZ and HAFEZ, 2000).

Study of the ultrastructure of the seminiferous tubule, epididymis, and vas deferens provides knowledge about reproductive biology. It also assists in clinical, surgical, pathological, and biological management (MENEZES, CARVALHO, ASSIS NETO et al., 2003) of endangered species (International Union for Conservation of Nature and Natural Resources, IUCN, 2013) to ensure their preservation and improvement.

Recently, we reported on the ultrastructure of spermatogenesis, sexual development, and testicular development in Galea spixii (SANTOS, OLIVEIRA, ARROYO et al., 2014; SANTOS, OLIVEIRA, SILVA et al., 2012). The aim of this study was to add new information about male genital organs of G. spixii with a focus on the ultrastructure of the epididymis and vas deferens.

\section{Material and Methods}

\subsection{Animals and tissue collection}

The Ethics Committee for the Use of Animals at the University of São Paulo (FMVZ/USP) authorized all experimental procedures (Protocol: 2486/2011). Capture and captivity of the cavies were authorized by the Brazilian institution responsible for wild animal care (Instituto Brasileiro do Meio Ambiente, IBAMA, Protocol: 2028236/2008).

Ten animals were collected at Mossoró, Rio Grande do Norte, Brazil (37²0'39'W, 6 ${ }^{\circ} 12^{\prime} 43$ 'S), and were held in the histology laboratory at the Veterinary Medicine and Animal Science School (FMVZ - University of São Paulo). Cavies were divided into the following groups based on stage of sexual development, as previously established (SANTOS, OLIVEIRA, SILVA et al., 2012): immature $(n=2)$, pre-pubertal $(n=2)$, pubertal $(n=4)$ and post pubertal $(n=2)$.

Tissues of the epididymis and vas deferens of cavies in all groups were collected by orchiectomy. During the procedure, animals were anesthetised with $0.025 \mathrm{mg} \mathrm{mL}^{-1}$ of atropine sulphate (Laboratórios Sintofarma S.A., São Paulo, São Paulo, Brazil - subcutaneous) and $0.2 \mathrm{mLkg}^{-1}$ of Zoletil (Virbac Saúde Animal $^{\circ}$, São Paulo, São Paulo, Brazil - intramuscular).

\subsection{Scanning Electron Microscopy (SEM)}

After collection, tissues were fixed in $2.5 \%$ glutaraldehyde in $0.1 \mathrm{M}$ buffer, $\mathrm{pH} 7.4$, and postfixed in $1 \%$ osmium tetroxide (SEMVR, Hatfield, Pennsylvania, PA). Then tissues were dehydrated in increasing concentrations of ethanol (70-100\%) and dried in a critical point dryer (Balzers UnionVR Critical Point CPD 020, Liechtenstein, Germany). Subsequently, fragments were placed in stubs and covered with gold in a sputter coater (EmitechVR K500, Ashford, Kent, England). Finally, samples were analysed under a scanning electron microscope (LEO 435 VP-Zeiss, Cambridge, England).

\subsection{Transmission Electron Microscopy (TEM)}

Tissues were fixed in $2.5 \%$ glutaraldehyde for 24 hours and post-fixed in $1 \%$ osmium tetroxide solution for $2 \mathrm{~h}$ at $4{ }^{\circ} \mathrm{C}$. 
Then tissues were dehydrated in an increasing series of alcohol (70-100\%), treated with propylene oxide, and infiltrated with a 1:1 mixture of pure resin and propylene oxide (Spurr's kit-Electron Microscopy Sciences, Co., Applied Biosystems, Foster City, CA, USA). After embedding in Spurr resin, tissues were kept in an oven at $60{ }^{\circ} \mathrm{C}$ for 3-5 days until complete polymerization had occurred. For light microscopy, sections $1 \mu \mathrm{m}$ thick were stained with toluidine blue. For observations of ultrastructure, thin silver sections were cut with a Leica ${ }^{\circledR}$ ultramicrotome (Leica Microsystems Inc., Buffalo Grove, IL, USA) using glass and diamond knives. Sections were then stained with lead citrate and examined with an electron microscope, and electron-micrographs were obtained (Morgagni 268D, FEI Company - PHILIPS; SIS DOCU TEM; digital camera 268, Hillsboro, OR, USA).

\section{Results}

This is the one of few reports on Galea spixii male genital organs during sexual development. Our results revealed morphological changes in male sexual organs. Moreover, sperm were observed in the tubular lumen from puberty onward.

The epididymis underwent morphological changes during sexual development. It had a pseudostratified, columnar, and stereociliated epithelium in all sexual phases (Figure 1). The peritubular stroma was composed of connective tissue, collagen fibers and blood vessels. With aging, the stroma was reduced due to an increase in ducts. Was observed a luminal increase during sexual stages of Galea spixii: immature $(18.05 \pm 2.58 \mu \mathrm{m})$, pre-pubertal $(34.01 \pm 1.19 \mu \mathrm{m})$, pubertal $(78.47 \pm 0.56 \mu \mathrm{m})$ and post-pubertal $(122.96 \pm 3.57 \mu \mathrm{m})$.
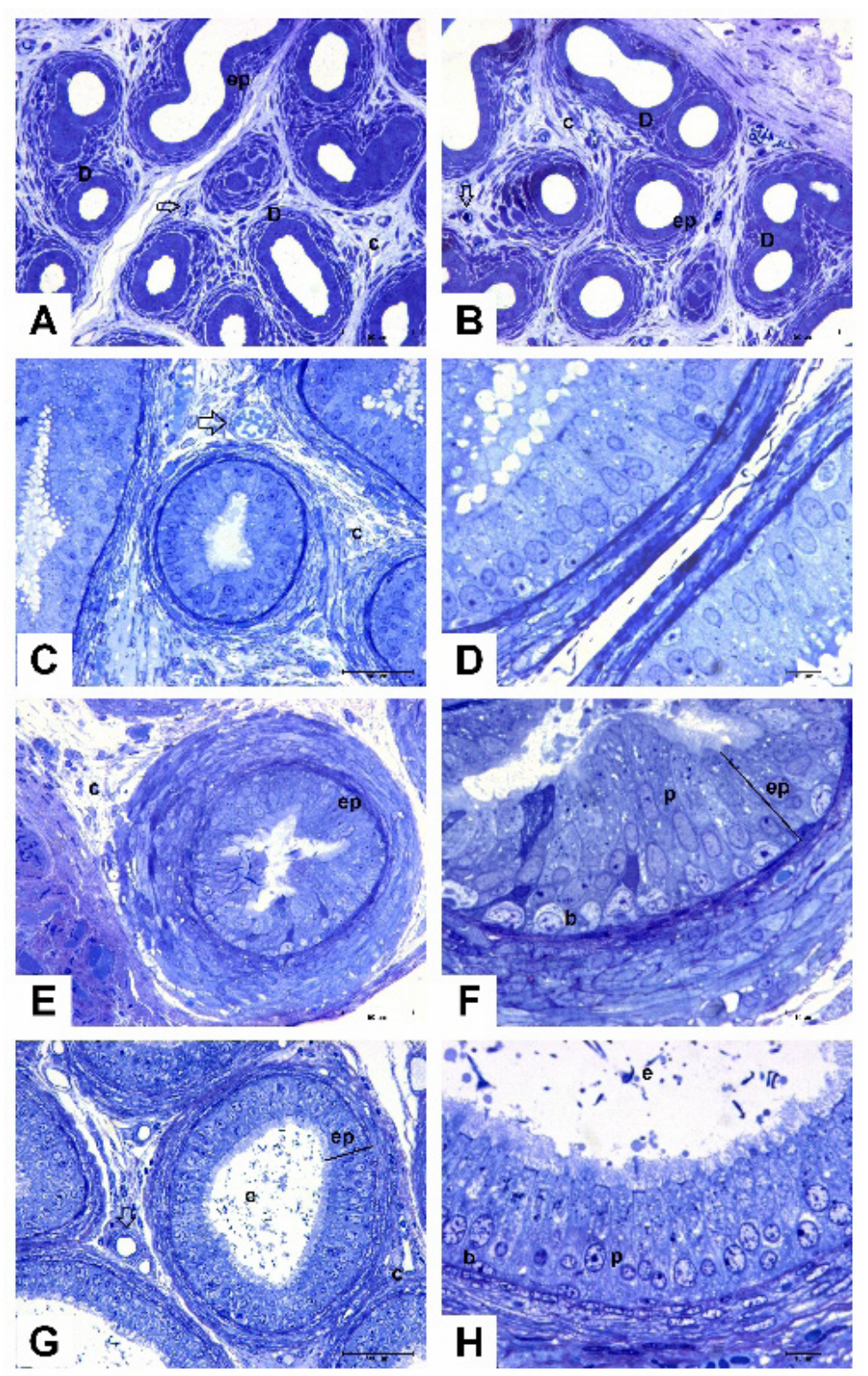

Figure 1. Epididymis, G. spixii, immature (A, B); prepubertal (C, D); pubertal (E, F) and post-pubertal (G, H). Note the evolution of the development of the epididymal duct (D). Note for the first time the presence of sperm at puberty (e). Interstitial space composed of loose connective tissue (c) and blood vessels (arrow). The epithelium (ep) varies from pseudostratified columnar cells to simple columnar cells with a predominance of principal cells (p) and basal cells (b). Scale bars: (A-C, E) $50 \mu \mathrm{m}$; (D, F, H) $10 \mu \mathrm{m}$, and $(\mathrm{G}) 100 \mu \mathrm{m}$. Toluidine blue. 
Scanning electron microscopy showed luminal development as well as the first presence of sperm in pubertal animals (Figure 2).

Two cell types could be identified in the epididymal epithelium. Basal cells had an ovoid-shaped nucleus that occupied most of the cytoplasm. These cells were near the basement membrane of the duct. Mitochondria, the endoplasmic reticulum, and the Golgi complex were rarely seen (Figure 3B). Principal cells dominated the epididymal epithelium. Their nuclei were circular, and an expanded cytoplasm was present. Higher organelles, such as mitochondria, the endoplasmic reticulum, the Golgi complex, and secretory vesicles, were also seen (Figure 3A).

Beyond the epididymis was the vas deferens, a sperm conduit. Cross sections of different segments of the vas deferens were studied. All segments were composed of a muscular layer, lamina propria, and epithelium lumen (Figure 4). The mucosa displayed variation in the creases of the epithelium, which was pseudostratified, columnar, and stereociliated, with cells of different shapes and sizes (Figure 4C,F,I). In all sexual phases, the epithelium was surrounded by two muscle layers, the innermost layer in a circular arrangement, and the distal layer in a longitudinal orientation (Figures 4 and 5).

Two cell types were observed in the vas deferens. Principal cells were elongated with clear cytoplasm whereas basal cells were rounded and had clear cytoplasm (Figure 6). The epithelium rested on a basal lamina followed by connective tissue, with a pleated appearance of the mucosa (Figures 4 and 7).

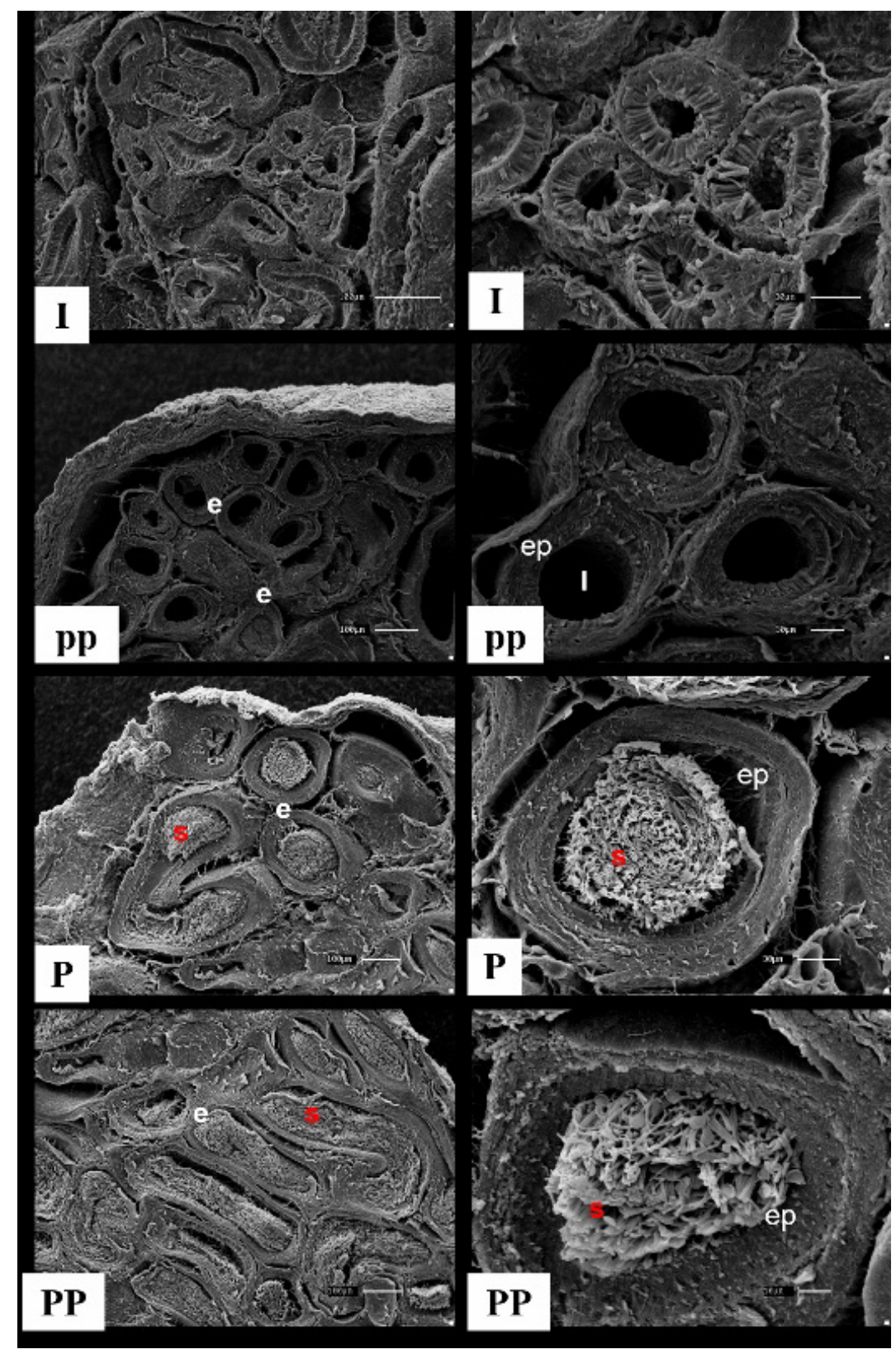

Figure 2. Epididymis, G. spixii, Immature (I); Prepubertal (pp); Pubertal (P) and Post-pubertal (PP). Note the increasing tubular development. Epididymal ducts (e) are lined with a simple columnar epithelium (ep). No sperm (s) are present at immature and prepubertal phases. SEM. 

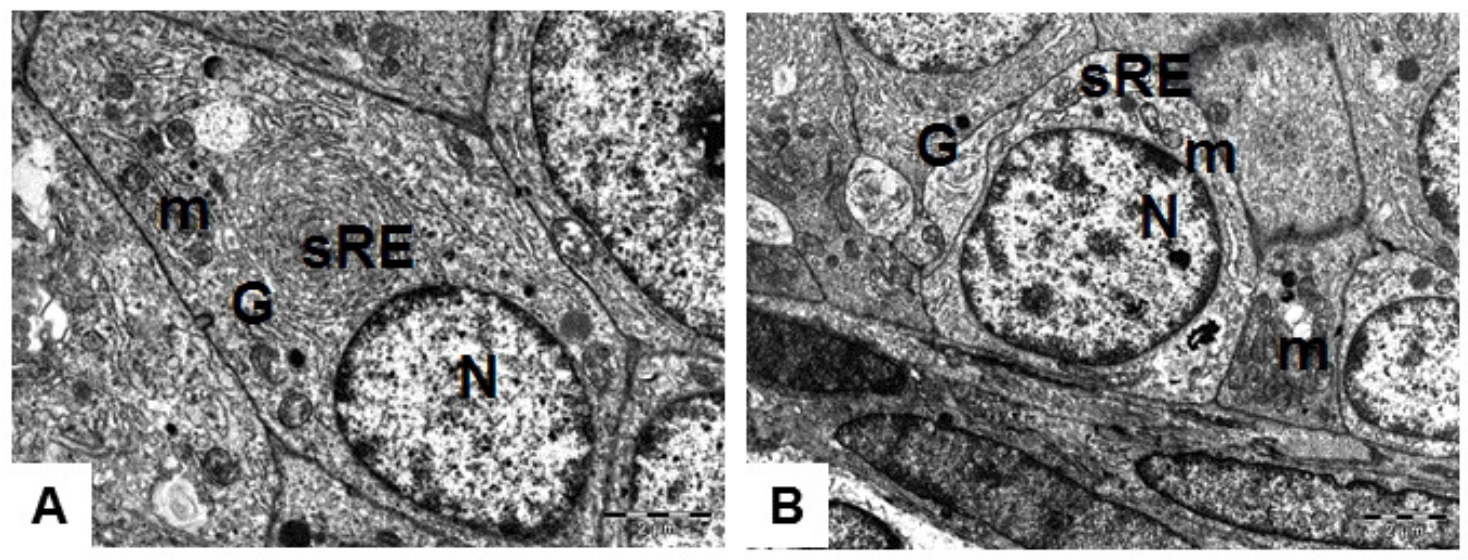

Figure 3. Epididymal epithelial cells, G. spixii. (A) principal cell; (B) basal cell. ( $\mathrm{G}=$ Golgi complex; $\mathrm{m}=$ mitochondria; $\mathrm{sRE}=$ smooth ER; $\mathrm{N}=$ nucleus). Scale bar: $2 \mu \mathrm{m}$. TEM.

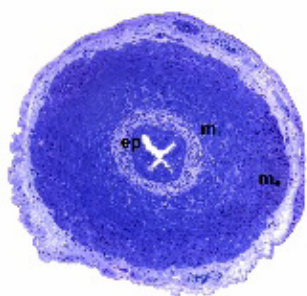

A

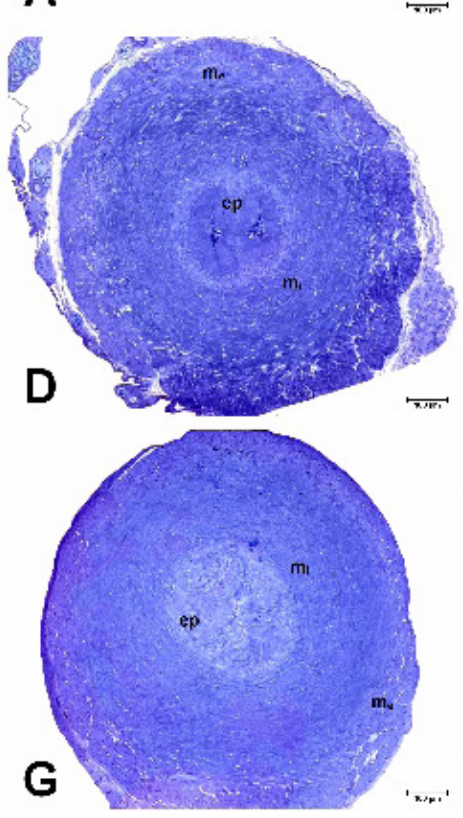

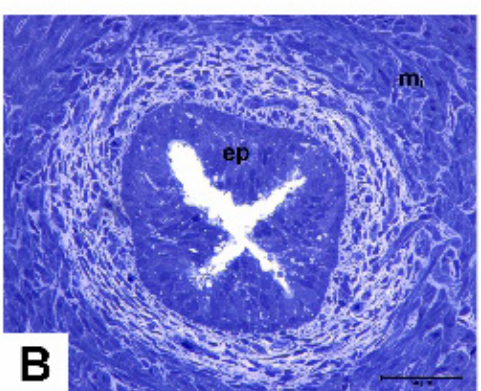
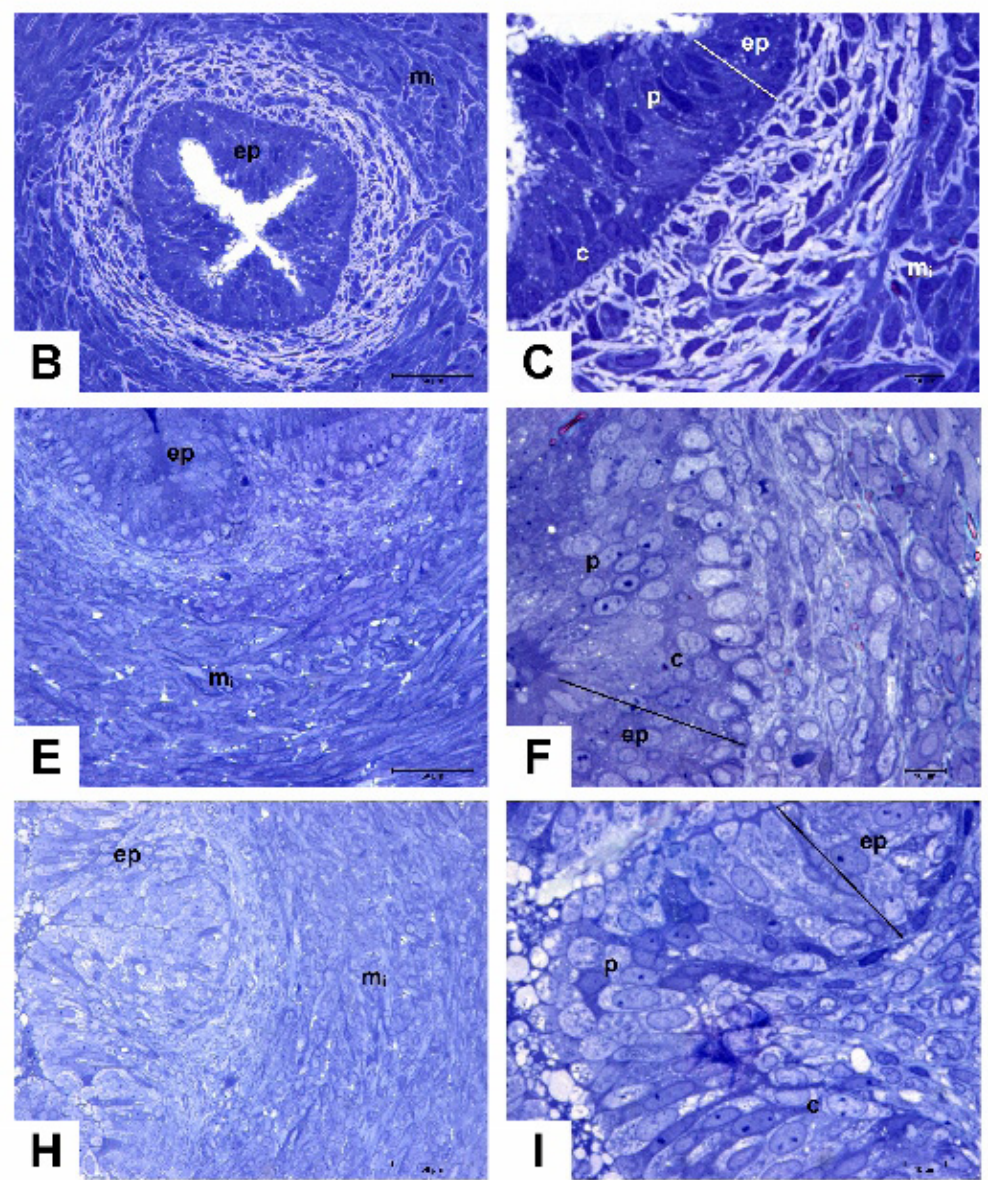

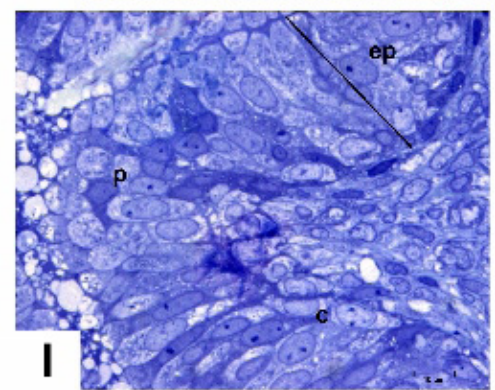

Figure 4. Vas deferens, G. spixii immature (A-C); prepubescent (D-F); and pubescent (G-I). Note the mucosa surrounded by an inner muscular layer ( $\mathrm{mi}$ ) and an outer longitudinal one (me). The epithelium (ep) is pseudostratified, columnar, and sterociliated. Principal cells (p) have clear cytoplasm, and basal cells (c) are circular, supported by the lamina propria. Scale bars: (A-C) $(100 \mu \mathrm{m} / 50 \mu \mathrm{m} / 10 \mu \mathrm{m})$; (D-F) $(100 \mu \mathrm{m} / 50 \mu \mathrm{m} / 10 \mu \mathrm{m})$; (G-I) $(100 \mu \mathrm{m} / 50 \mu \mathrm{m} / 10 \mu \mathrm{m})$. Toluidine blue.

\section{Discussion}

After birth, morphological and physiological changes occurred in the genital organs of G. spixii. Principal morphological changes observed in the epididymis and vas deferens of G. spixii were luminal increase and the presence of sperm at puberty.
The luminal increase, the pseudostratified columnar, and stereociliated epithelium of the G. spixii epididymal are similar to other rodents such as the agouti (ARROYO, OLIVEIRA, SANTOS et al., 2014), bandicoot rat (AMIYA and MAITI, 1982), hamster (NICANDER and GLOVER, 1973), mexican rodent (LORENZANA, LOPEZ-WILCHIS, 


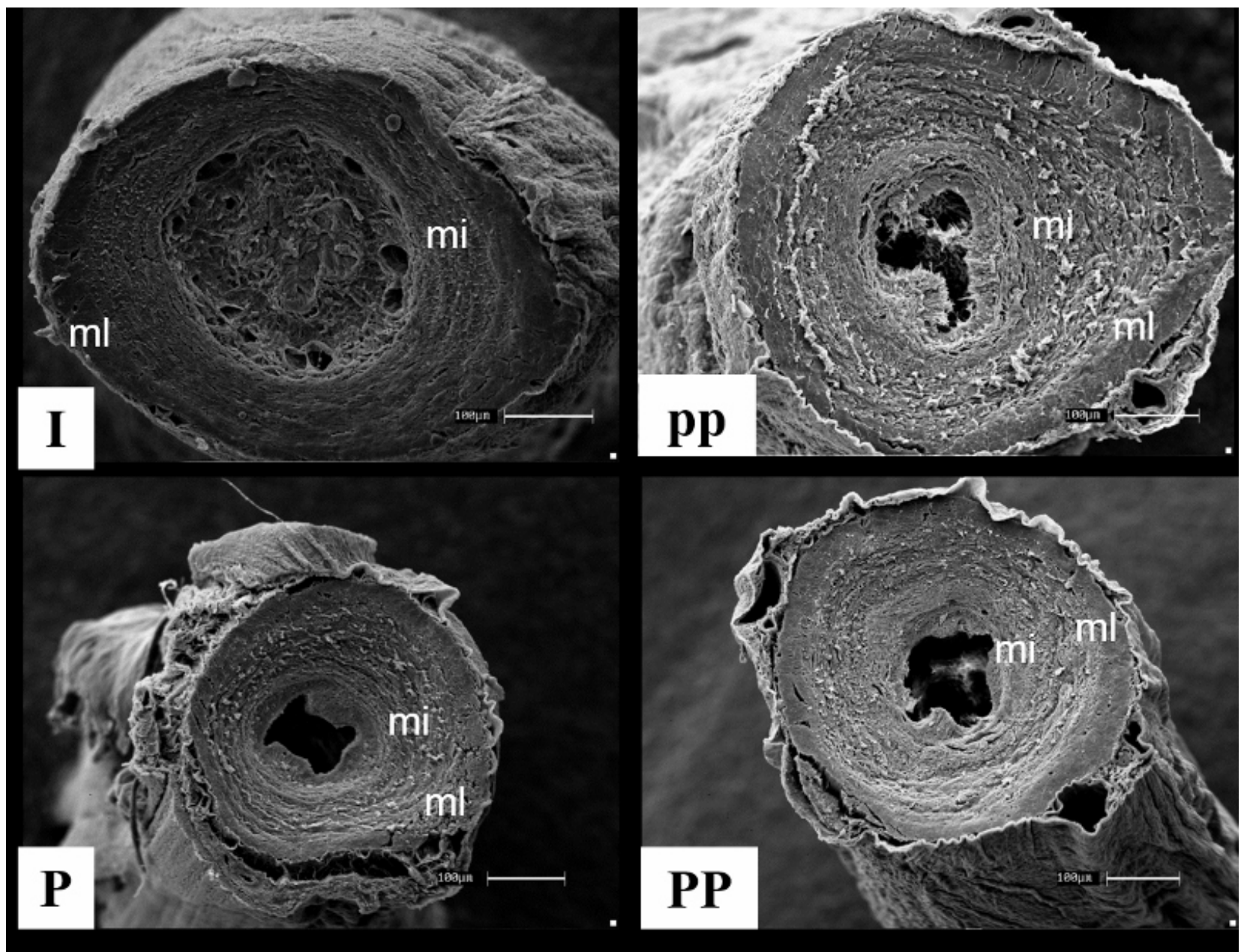

Figure 5. Vas deferens, G. spixii, Immature (I); Prepubertal (pp); Pubertal (P) and Post-pubertal (PP). Inner muscular layer (mi) and an outer longitudinal one $(\mathrm{ml})$. Note the undeveloped lumen in "I". SEM.

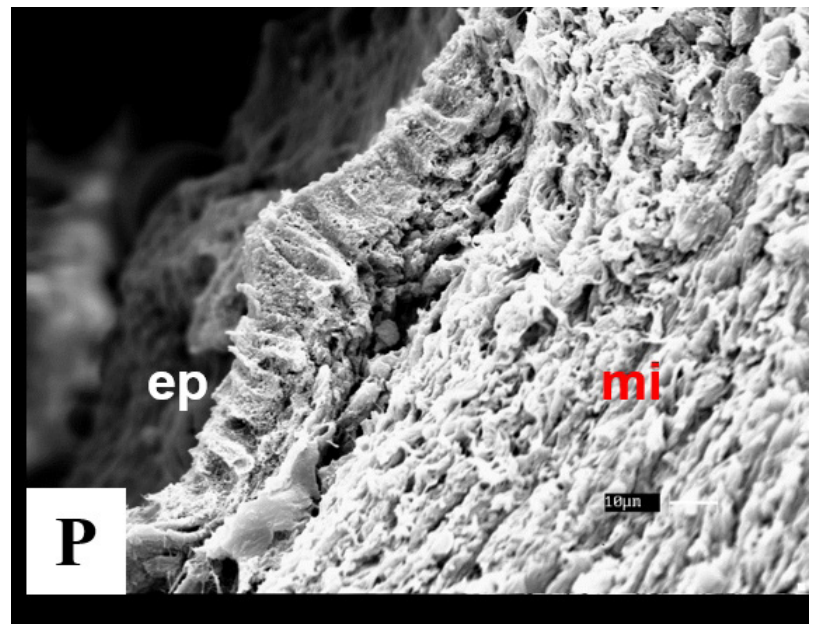

Figure 6. Vas deferens, G. spixii, Pubertal (P). Evident are the inner (mi) muscle layers of the duct and the pseudostratified epithelium (ep). SEM.

GOMEZ et al., 2007), and mouse (ABE, TAKANO and ITO, 1982). The luminal increase contributes to the maturation and storage of spermatozoa (LORENZANA, LOPEZ-WILCHIS, GOMEZ et al., 2007).
Two cell types are prevalent throughout the epididymal epithelium in G. spixii: principal and basal cells. However, halogen, apical and clear cells have also been reported in rodents (ARROYO, OLIVEIRA, SANTOS et al., 2014; ROBAIRE, HINTON and ORGEBIN-CRIST, 2006). In this study, principal cells are columnar with stereocilia extending from the basement membrane to the lumen. The presence of the Golgi apparatus, mitochondria, vesicular corpuscles and endoplasmic reticulum were observed in the supra and infra-nuclear regions, as in agoutis (ARROYO, OLIVEIRA, SANTOS et al., 2014). These cells are responsible for protein secretion and absorption into the lumen (ROBAIRE, HINTON and ORGEBIN-CRIST, 2006).

Basal cells of G.spixii had the same morphology as other mammals (KERR, LOVELAND, O'BRYAN et al., 2006). Their basal membrane is associated with principal cells via cytoplasmic extensions for the regulation of electrolytes. Basal cells are also responsible for epithelial immunity and antioxidant production (ARROTÉIA, GARCIA and BARBIERI, 2012). Both basal and principal cells promote maturation and sperm motility. These observations have been reported in hamsters, rats, rabbits, and dogs (PRYOR, 1996)

During ejaculation, coordinated muscular contractions propel the sperm toward the urethra. (DIXON, JEN and 

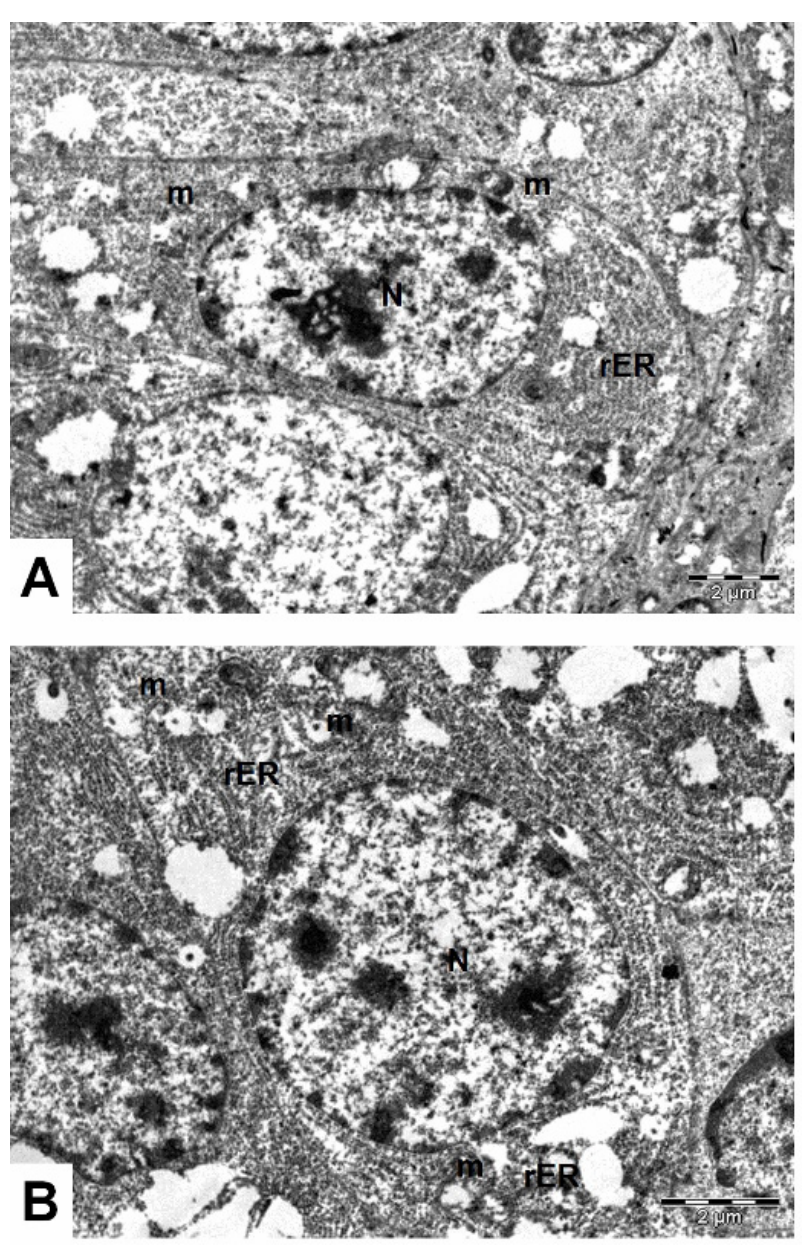

Figure 7. Vas deferens, G. Spixii, epithelial cells of the vas deferens. (A) principal cell; (B) basal cell. ( $\mathrm{G}=$ Golgi complex; $\mathrm{m}=$ mitochondria; $\mathrm{rER}=$ rough endoplasmatic reticulum; $\mathrm{N}=$ nucleus). Scale bar: $2 \mu \mathrm{m}$. TEM.

GOSLING, 1998). For this, structurally, the vas deferens of G.spixii consists of a muscular layer and mucosa. The muscle layer is smooth and composed of a circular, spiral-shaped muscle and a helical, longitudinal muscle. The morphological composition of epithelium and muscle layers is similar to that described in the bandicoot rat (AMIYA and MAITI, 1982), rat (NIEMI, 1973), coati (FRANCIOLLI, COSTA, MANÇANARES et al., 2007), sand male rat (SPRANDO, COLLINS, BLACK et al., 1999).

The epithelium of the vas deferens of G. spixii resembles that of the epididymis, in that it consists of pseudostratified, columnar cells with stereocilia. As in other mammals, the lumen has an irregular shape (KOSLOV and ANDERSSON, 2013). Principal and basal cells founds in G. spixii are probably engaged in protein and glycoprotein synthesis, as well as sperm reabsorption in vas deferens (HEIDGER and SAWATZKE, 1977; KOSLOV and ANDERSSON, 2013)

This study aims to examine changes in the reproductive tract of Galea spixii males and to describe changes in the epididymis and vas deferens during sexual development using electron microscopy. As in the G. spixii testis (SANTOS, OLIVEIRA, SILVA et al., 2012), sperm were present at puberty. Also we can say that the luminal increased epididymis was similar to that seen in the seminiferous tubules of the Galea spixii testis development (SANTOS, OLIVEIRA, SILVA et al., 2012).

Acknowledgements: This work was supported by the São Paulo State Research Foundation (FAPESP - grant numbers 2010/14516-0). We thank members of the Faculty of Veterinary Medicine and Animal Science (University of São Paulo), Brazil, and Dr. Rose Eli Grassi Rici for technical support. We warmly thank Rose Kastelic for help with the English.

\section{References}

ABE, K., TAKANO, H. and ITO, T. Response of the, epididymal duct in the corpus epididymidis to efferent of epididymal duct ligation in the mouse. Journal of Reproduction and Fertility, 1982, vol. 64, n. 1, p. 69-72. PMid:6275082. http://dx.doi.org/10.1530/jrf.0.0640069.

AMIYA, PSH. and MAITI, BR. Quantitative studies of the reproductive organs of the male bandicoot rat: a common rodent pest. Anatomischer Anzeiger, 1982, vol. 151, n. 5, p. 483-495. PMid:7137576.

ARROTÉIA, KF., GARCIA, PV. and BARBIERI, MF. The Epididymis: embryology, structure, function and its role in fertilization and infertility. In PEREIRA, LV. (Ed.). Embryology: updates and highlights on classic topics. InTech, 2012. p. 41-66.

ARROYO, MAM., OLIVEIRA, MF., SANTOS, PR. and ASSIS NETO, AC. Ultrastructure of the epididymis and vas deferens of agoutis at different stages of sexual development. Animal Reproduction Science, 2014, vol. 149, n. 3-4, p. 273-280. PMid:25028182. http://dx.doi. org/10.1016/j.anireprosci.2014.05.006.

COSTA, DS., HENRY, M. and PAULA, TAR. Espermatogênese de catetos (Tayassu tajacu). Arquivo Brasileiro de Medicina Veterinária e Zootecnia, 2004, vol. 56, n. 1, p. 46-51. http://dx.doi.org/10.1590/ S0102-09352004000100008.

DIXON, JS., JEN, PYP. and GOSLING, JA. Structure and autonomic innervation of the human vas deferens : a review. Microscopy Research and Technique, 1998, vol. 42, n. 6, p. 423-432. PMid:9817549. http:// dx.doi.org/10.1002/(SICI)1097-0029(19980915)42:6<423::AIDJEMT5>3.0.CO;2-N.

EBERHARD, WG. Sexual selection and animal genitalia. Cambridge: Harvard University Press, 1985. 244 p.

FRANCIOLLI, ALR., COSTA, GM., MANCANARES, CAF., MARTINS, DS., AMBRÓSIO, CE., MIGLINO, MA. and CARVALHO, AF. Morfologia dos órgãos genitais mas-culinos de quati (Nasua nasua Linnaeus, 1766). Biotemas, 2007, vol. 20, n. 1, p. 27-36.

HAFEZ, ESE. and HAFEZ, B. Reproduction in farm animals. 6th ed. São Paulo: Manole, 2000. 509 p.

HEIDGER, PMJ. and SAWATZKE, C. Fine structural effects of vasectomy on the male reproductive system. In YATES, R. and GORDON, M. (Eds.). The male reproductive system. New York: Masson, 1977. p. 131-153.

KERR, JB., LOVELAND, KL., O'BRYAN, MK. and KRETSER, DM. Knobil and Neill's physiology of reproduction: cytology of the testis and intrinsic control mechanisms. New York: Academic Press, 2006. 3296 p.

KOSLOV, DS. and ANDERSSON, KE. Physiological and pharmacological aspects of the vas deferens-an update. Frontiers in Pharmacology, 2013, vol. 4, p. 1-11. PMid:23986701. http://dx.doi.org/10.3389/ fphar.2013.00101.

LORENZANA, MG., LOPEZ-WILCHIS, R., GOMEZ, CS. and ARANZABAL, MCU. A light and scanning electron microscopic study of the epididymis active state of the endemic Mexican rodent peromyscus winkelmanni (Carle- ton) (Rodentia: Muridae). Anatomia, Histologia, Embryologia, 2007, vol. 36, n. 3, p. 230-240. PMid:17535358. http://dx.doi.org/10.1111/j.1439-0264.2006.00752.x. 
MENEZES, DJA., CARVALHO, MAM., ASSIS NETO, AC., OLIVEIRA, MF., FARIAS, EC., MIGLINO, MA. and MEDEIROS, GX. Morfologia dos órgãos genitais externos do macho de cutia (Dasyprocta agouti. Linnaeus, 1766). Brazilian Journal of Veterinary Research and Animal Science, 2003, vol. 40, p. 148-153. http:// dx.doi.org/10.1590/S1413-95962003000800009.

NICANDER, L. and GLOVER, TD. Regional histology and fine structure of the epididymal duct in the golden hamster (Mesocricetus auratus). Journal of Anatomy, 1973, vol. 114, n. Pt 3, p. 347-364. PMid:4716139.

NIEMI, M. The fine structure and histochemistry of the epithelial cells of the rat vas deferens. Acta Anatomica, 1973, vol. 60, n. 1, p. 207-219. PMid:14314648.

PRYOR, JP. Surgical opportunities to explore the function of the human epididymis. Annals of the Royal College of Surgeons of England, 1996, vol. 78, n. 1, p. 49-55. PMid:8659974.

ROBAIRE, B., HINTON, BT. and ORGEBIN-CRIST, MC. The epididymis. In Neill, JD., Plant, TM., Pfaff, DW., Challis, JRG., Kretser, DM., Richards, JAS. and Wassarman, PM. (Eds.). Knobil and Neill's physiology of reproduction. New York: Elsevier, 2006. p. 1071-1148.

SANTOS, PRS., OLIVEIRA, MF., ARROYO, MAM., SILVA, AR., RICI, REG., MIGLINO, MA. and ASSIS NETO, AC. Ultrastructure of spermatogenesis in Spix's yellow-toothed cavy (Galea spixii).
Reproduction (Cambridge, England), 2014, vol. 147, n. 1, p. 1319. PMid:24101585. http://dx.doi.org/10.1530/REP-13-0452.

SANTOS, PRS., OLIVEIRA, MF., SILVA, AR. and ASSIS NETO, AC. Development of spermatogenesis in captive-bred Spix's yellowtoothed cavy (Galea spixii). Reproduction, Fertility, and Development, 2012, vol. 24, n. 6, p. 877-885. PMid:22781939. http://dx.doi. org/10.1071/RD12015.

SHORT, RV. Sexual selection and its component parts, somatic and genital selection, as illustrated by man and the great apes. Advances in the Study of Behavior, 1979, vol. 9, p. 131-158. http://dx.doi. org/10.1016/S0065-3454(08)60035-2.

SPRANDO, RL., COLLINS, TFX., BLACK, TN., OLEJNIK, N., RORIE, JL., WEST, LJ., BO-WERS, JD., SASS, N. and ROBL, M. Light microscopic observations on the reproductive tract of the male sand rat, Psammomys obesus. Tissue \& Cell, 1999, vol. 31, n. 1, p. 99115. PMid:10368991. http://dx.doi.org/10.1054/tice.1999.0003.

THE IUCN RED LIST OF THREATENED SPECIES. IUCN Red List of Threatened Species: version 2013. Cambridge, 2013. Available from: <www.iucnredlist.org>. Access in: 3 Sept. 2013.

Received: June 12, 2015 Accepted: October 19, 2016 